\title{
Links between ultramafic lamprophyres and kimberlites in the Anabar shield, Yakutia, Russia: evidence from multiphase inclusions in rock-forming minerals
}

\author{
A.V. KARGIN ${ }^{1 *}$, V.S. KAMENETSKY ${ }^{2}$ \\ ${ }^{1}$ Institute of Geology of Ore Deposits, Petrography, \\ Mineralogy and Geochemistry RAS, Moscow, Russia \\ (*correspondence: kargin-igem@mail.ru) \\ ${ }^{2}$ School of Natural Sciences, Univ. of Tasmania, Hobart, \\ Tasmania, Australia (dima.kamenetsky@utas.edu.au)
}

To provide new constraints on the evolution of ultramafic lamprophyre melts and relation to kimberlites, we examined monomineralic and primary multiphase melt inclusions in rock-forming minerals within damtjernite from Viktoria pipe, Anabar region, Siberia craton, Russia. The studied samples are relatively unaltered nepheline-bearing, carbonate-poor damtjernite with a significant amount of monticellite in the groundmass and as a replacement of olivine.

Studied inclusions hosted by groundmass monticellite, magnesian ulvöspinel-magnetite and perovskite. Monomineralic inclusions sized up to $10 \mu \mathrm{m}$ are round-toeuhedral in shape and are comprised of monticellite, spinel, perovskite and nepheline. Multiphase melt inclusions sized up to $10-15 \mu \mathrm{m}$ have rounded to elongate and amoeboid shapes. These inclusions are heterogeneous in composition and consist of perovskite, spinel group minerals, apatite (including F- and Sr-apatite), feldspathoids, multiphase alkali (Na, K) carbonate and chloride (sylvite/halite), rare K-Naand Ba-sulfates, phlogopite and baddeleyite.

Despite the lack of carbonate phases in studied rocks, the composition of multiphase inclusions indicates that lamprophyre melts contained carbonate or carbonate/chlorite components. The $\mathrm{CO}_{2}$ degassing is consistent with the reaction between olivine and carbonate-bearing melt led to decarbonation reaction and generation of montichellite, as described in [1].

The composition of multiphase inclusions within minerals from lamprophyres is close to the composition of multiphase inclusions within olivine, spinel, monticellite, perovskite from kimberlites, thus indicating possible genetic links between parental melts of ultramafic lamprophyre and kimberlite.

This study was supported by the Russian Foundation for Basic Research, project nos. 18-05-00644a.

[1] Abersteiner et al. (2018) Chem.Geology 478, 76-88. 